\title{
Aspek Hukum Prinsip Tata Kelola Perusahaan yang Baik dan Penerapannya pada Badan Usaha Milik Desa
}

\author{
Maria Fransiska Owa da Santo ${ }^{1 *}$, Yustinus Pedo ${ }^{2}$ \\ ${ }^{1,2}$ Fakultas Hukum Universitas Katolik Widya Mandira, Kupang, Indonesia \\ *E-mail: siscadasanto@gmail.com
}

\begin{tabular}{|c|c|}
\hline Dikirim: $17 / 03 / 2020$ & Dipublikasi: 03/09/2020 \\
\hline Info Artikel & Abstract \\
\hline $\begin{array}{l}\text { Keywords: } \\
\text { Legal Aspects; } \\
\text { Principles of Good } \\
\text { Corporate } \\
\text { Governance; Village- } \\
\text { Owned Enterprises. }\end{array}$ & $\begin{array}{l}\text { Villages in the era of regional autonomy have the authority to determine } \\
\text { the direction of development by optimizing the management of village } \\
\text { funds through the establishment and development of Village-Owned } \\
\text { Enterprises (BUMDES). This study aims at the concern of villages in } \\
\text { NTT Province that have not made BUMDES as a vehicle for managing } \\
\text { the Village Fund and as a comparison for researchers who took the } \\
\text { research location in Kokbaun District, TTS Regency, NTT Province. This } \\
\text { research is a descriptive legal research with the type of research is } \\
\text { normative-empirical legal research. This type of research requires } \\
\text { secondary data and primary data. The research data shows that the } \\
\text { Village Government in Kokbaun District has understood the importance } \\
\text { of establishing BUMDES as mandated by the Village Law, but there are } \\
\text { obstacles in the implementation of its formation and development. The } \\
\text { obstacles are the quality of Human Resources, namely the lack of } \\
\text { understanding of villagers and the lack of skilled personnel in managing } \\
\text { BUMDES in accordance with the articles of association and bylaws and } \\
\text { understanding of village development. The principles of good corporate } \\
\text { governance can help BUMDES management so that it becomes more } \\
\text { focused and ultimately can increase village income which will also affect } \\
\text { the development and economic development of rural communities. }\end{array}$ \\
\hline $\begin{array}{l}\text { Kata Kunci: } \\
\text { Aspek Hukum; } \\
\text { Prinsip Tata Kelola } \\
\text { Perusahaan; Badan } \\
\text { Usaha Milik Desa. }\end{array}$ & $\begin{array}{l}\text { Abstrak } \\
\text { Desa dalam era otonomi daerah memiliki kewenangan untuk } \\
\text { menentukan arah pembangunan dengan mengoptimalkan pengelolaan } \\
\text { dana desa melalui pembentukan dan pengembangan Badan Usaha Milik } \\
\text { Desa (BUMDES). Penelitian ini bertujuan terhadap kepedulian desa- } \\
\text { desa di Provinsi NTT yang belum menjadikan BUMDES sebagai salah } \\
\text { satu wadah dalam pengelolaan Dana Desa dan sebagai perbandingan } \\
\text { peneliti yang mengambil lokasi penelitian di Kecamatan Kokbaun, } \\
\text { Kabupaten TTS, Provinsi NTT. Penelitian ini merupakan penelitian } \\
\text { hukum deskriptif dengan jenis penelitian hukum normatif-empiris. Jenis } \\
\text { penelitian ini membutuhkan data sekunder dan data primer. Data } \\
\text { penelitian menunjukkan bahwa Pemerintah Desa di Kabupaten }\end{array}$ \\
\hline
\end{tabular}


DOI:

10.47268/sasi.v26i3.274

Kokbaun telah memahami pentingnya pendirian BUMDES sesuai amanat UU Desa, namun terdapat kendala dalam pelaksanaan pembentukan dan pengembangannya. Kendala tersebut adalah kualitas Sumber Daya Manusia yaitu kurangnya pemahaman warga desa dan kurangnya tenaga terampil dalam mengelola BUMDES sesuai dengan anggaran dasar dan anggaran rumah tangga serta pemahaman tentang pembangunan desa. Prinsip-prinsip tata kelola perusahaan yang baik dapat membantu pengelolaan BUMDES agar lebih terarah dan pada akhirnya dapat meningkatkan pendapatan desa yang juga akan berpengaruh pada perkembangan dan perkembangan ekonomi masyarakat pedesaan.

\section{A. PENDAHULUAN}

Dalam perkembangannya hukum merupakan cermin yang menggambarkan kepentingan masyarakat yang selalu mengalami perubahan dari waktu kewaktu. Untuk menjawabi perubahan ini, maka hukum juga dituntut untuk selalu merubah dirinya sehingga dapat menyesuaikan dengan perkembangan dan perubahan dalam masyarakat. Dalam melakukan perubahan, hukum telah bergerak dari represissve law menjadi autonomous law dan kemudian menjadi responsive law sebagai fase yang paling maju dalam perkembangan hukum, bahkan untuk masa ini hukum sedang dikembangkan kearah hukum yang progresif atau progresive law. ${ }^{1}$

Salah satu langkah menjawab perubahan kebutuhan masyarakat dalam menghadapi era globalisasi adalah pemberian otonomi daerah kepada daerah untuk mengurus daerahnya secara bertanggung jawab. Kebijakan otonomi daerah hadir untuk menjawab berbagai persoalan diantaranya, pertama, otonomi daerah menjawab permasalahan ditingkat daerah yang mengalami ancaman kemiskinan, masalah pembangunan sumber daya manusia serta rendahnya kualitas hidup masyarakat; kedua, otonomi daerah membantu pemerintah daerah khususnya dan bangsa Indonesia umumnya untuk menghadapi era globalisasi ekonomi. Jadi, kebijakan pemberian otonomi daerah dan desentralisasi yang luas, nyata, dan bertanggung jawab kepada daerah merupakan langkah strategis. ${ }^{2}$

Pemberian otonomi daerah diharapkan dapat memacu daerah dalam pembangunan daerah melalui usaha-usaha yang mampu meningkatkan partisipasi aktif masyarakat, karena pada dasarnya terkandung tiga misi utama sehubungan dengan pelaksanaan otonomi daerah, yaitu: a) Menciptakan efisiensi dan efektivitas pengelolaan sumber daya daerah; b) Meningkatkan kualitas pelayanan umum dan kesejahteraan masyarakat; c) Memberdayakan dan menciptakan ruang bagi masyarakat untuk ikut serta (berpartisipasi) dalam proses pembangunan. ${ }^{3}$ Hakekatnya otonomi daerah mengharapkan daerah mempunyai kemampuan dalam menggali dan mengembangkan sumber daya yang dimiliki sehingga kemampuan ekonomi daerah mampu membiayai berbagai kepentingan pembangunan di daerah. Salah satu sumber pendapatan yang harus terus digali dan dikembangkan di daerah adalah Pendapatan Asli Daerah (PAD). Pendapatan Asli Daerah adalah komponen yang harus dikelola secara lebih efisien dan efektif oleh daerah agar semakin kuat peranannya sehingga dapat memperkecil ketergantungan pemerintah daerah pada pemerintah pusat di

1 Tanya L. Bernad, Simanjuntak N. Yoan, Hage Y. Markus. (2006), Teori Hukum, Strategi Tertib Manusia Lintas Ruang dan Generasi, Surabaya: Kita, h. 170-172.

2 Wikipedia. (2020). "Otonomi Daerah Di Indonesia”, Web Page, http://id.wikipedia.org/wiki/Otonomi_daerah_di_Indonesia, diakses tanggl 12 Januari 2020.

${ }^{3}$ Sani Abdul. (2017). "Media Informasi Otonomi Daerah Indonesia, Tujuan Otonomi Daerah", Web Page, http://otonomidaerah.com/tujuan-otonomi-daerah/, diakses tanggal 12 Januari 2020. 
bidang pembiayaan pembangunan.

Sebagai akibat dari lahirnya otonomi daerah maka kelanjutanya adalah lahirlah juga otonomi desa yang dasar hukumnya adalah Undang-Undang Nomor 6 Tahun 2014 tentang Desa. Dalam sejarah, desa merupakan awal dibentuknya masyarakat politik dan pemerintahan. Hal ini dapat dicermati dalam pertimbangan pembentukan Undang-Undang (UU) Desa, dimana keinginan pemerintah adalah untuk membentuk suatu kelembagaan desa yang lebih baik dan maju secara khusus dalam aspek ekonomi.

Salah satu aspek penekanan dalam pembentukan UU Desa dalam rangka menunjang pembangunan desa adalah pendirian Badan Usaha Milik Desa (BUMDES). Pembentukan BUMDES bertujuan sebagai penggerak pembangunan ekonomi mayarakat ditingkat desa. Pembangunan ekonomi ini dilandasi kepada kebutuhan, potensi, dan kapasitas desa dengan tujuan utamanyanya adalah meningkatkan taraf ekonomi masyarakat desa. ${ }^{4}$

Didalam Undang-Undang Nomor 6 Tahun 2014 tentang Desa, mendefenisikan BUMDES sebagai badan usaha yang seluruh atau sebagian besar modalnya dimiliki oleh Desa melalui penyertaan secara langsung yang berasal dari kekayaan Desa yang dipisahkan guna mengelola aset, jasa pelayanan dan usaha lainnya untuk sebesar-besarnya kesejahteraan masyarakat Desa. ${ }^{5}$ Di dalam UU Desa terdapat empat pasal yang menjelaskan mengenai BUMDesa, yaitu: Pasal 87 mengenai semangat yang melandasi pendirian dan pengelolaan BUMDesa Pasal 88 mengenai pendirian BUMDesa; Pasal 89 mengenai manfaat berdirinya BUMDesa; dan Pasal 90 mengenai arah pengembangan bisnis BUMDesa yang bermanfaat bagi masyarakat desa. Dari UU Desa tersebut dapat disimpulkan bahwa BUMDES memegang peranan penting dalam pengembangan potensi desa khususnya dalam mengelola keuangan desa yang ada di wilayahnya. ${ }^{6}$

Kehadiran UU Nomor 6 Tahun 2014 tentang Desa diharapkan seluruh pihak yang terkait mampu memberikan peran yang sesuai dan lebih membantu pemerintah desa didalam proses penyelenggaraan pemerintahan desa. Proses penyelenggaraan yang dimaksud adalah proses pelaksanaan pembangunan, pembinaan masyarakat dan pemberdayaan masyarakat desa yang sesuai dengan hak asal usul dan adat istiadat desa. Dalam hal ini adalah memberikan peran yang maksimal kepada BUMDES untuk mengembangkan kegiatan ekonomi perdesaan. ${ }^{7}$

Landasan hukum mengenai keberadaan dan tata kelola BUMDES, semakin diperjelas dengan keluarnya Permendesa PDTT (Pembangunan Daerah Tertinggal, dan Transmigrasi) Nomor 4 Tahun 2015 tentang Pendirian, pengurusan, pengelolaan dan Pembubaran Badan Usaha Milik Desa, walaupun sebenarnya pengaturan tentang hal ini telah diatur dalam Permendagri Nomor 113 Tahun 2014 tentang Pengelolaan Keuangan Desa, namun di dalam Permendagri tidak menyinggung mengenai BUMDES. Dalam Permendesa PDTT Nomor 4

4 Sofyan Ahmad. (2015). "Pendirian dan Pengelolaan BUMD”, Web Page, http://www.keuangandesa.com/2015/09/pendirian-dan-pengelolaan-badan-usaha-milik-desa/, diakses tanggal 12 Januari 2020.

${ }^{5}$ Forum Pengembangan Pembaharuan Desa. (2013). "Sharing Pembelajaran Bumdes Bagi Pemerintah Kabupaten/Kota", Web Page, http://www.forumdesa.org/?pilih=news\&mod=yes\&aksi=lihat\&id=1, diakses tanggal 14 Januari 2020.

6 Surya Putra Anom 2015. Badan Usaha Milik Desa: Spirit Usaha Kolektif Desa. Jakarta: Kementerian Desa, Pembangunan Daerah Tertinggal, Dan Transmigrasi Republik Indonesia https://www.academia.edu/11850491/_Free_Download_BUM_Desa_Spirit_Usaha_Kolektif_Desa, diakses tanggal 12 Jnuari 2020.

7 Shohibuddin M. (2016). Peluang dan Tantangan Undang-undang Desa dalam Upaya Demokratisasi Tata Kelola Sumber Daya Alam Desa: Perspektif Agraria Kritis, Masyarakat Jurnal Sosial, doi: 10.7454/mjs. Volume 21, Nomor 1. Tanpa h. 
Tahun 2015, dijelaskan secara lebih terperinci mengenai proses pendirian BUMDES, siapa saja yang berhak mengelola BUMDES, permodalan BUMDES, jenis usaha yang diperbolehkan, sampai dengan pelaporan dan pertangggung jawaban pelaporan BUMDES. Hal ini dapat membantu desa dalam melaksanakan pembentukan dan pendirian serta pengeloaann BUMDES yang benar dan bertanggung jawab. ${ }^{8}$ Keberadaan Permendesa yang mengatur tentang BUMDES diharapkan dapat memberikan penguatan kepada keberadaan BUMDES sebagai salah satu tulang punggung penopang perekomian masyarakat desa umumnya sehingga dapat dimanfaatkan secara benar dan bertanggung jawab bagi kesejahteraan masyarakat Desa.

Menurut Pasal 8 Permendesa PDTT Nomor 4 Tahun 2015, bentuk badan usaha BUMDES dapat berbentuk Perseroan Terbatas (PT), sesuai dengan peraturan perundangundangan tentang PT dan Lembaga Keuangan Mikro, sesuai dengan peraturan perundangundangan tentang Lembaga Keuangan Mikro.

Bentuk badan usaha BUMDES sebagaimana yang diatur dalam Permendesa ini merupakan salah faktor yang berperan penting adalah aspek tata kelola. Aspek Tata kelola BUMDES menjadi fokus utama yang harus diperhatikan karena dengan tata kelola yang baik maka akan berdampak pada pengelolaan BUMDES sebagai organisasi keuangan yang sehat ditingkat desa.

Di Indonesia tata kelola selalu dikaitkan dengan perusahaan, sehingga dikenal istilah tata kelola perusahaan yang baik. Menurut arti kata, kata tata kelola diartikan kepada istilah pengaturan, yang dalam konteks Tata Kelola Perusahaan yang Baik disebut sebagai tata pamong. Jadi pengertian tata kelola perusahaan yang baik adalah suatu sistem dan proses yang mengatur pola hubungan dalam organ perusahaan untuk memberikan nilai keuntungan kepada perusahaan secara berkesinambungan dan taat kepada peraturan perundangundangan dan selalu memperhatikan kebutuhan para pemangku kepentingan. ${ }^{9}$ Prinsip tata kelola perusahaan yang baik adalah upaya dilakukan oleh semua pihak yang mempunyai hubungan dengan perusahaan demi menjalankan perusahaan secara baik dengan memperhatikan hak dan kewajiban masing-masing pihak.

Istilah tata kelola perusahaan yang baik semakin sering digunakan karena dalam pelaksanaanya prinsip ini dapat mewujudkan kesuksesan bagi perusahaan yang sedang berkembang karena prinsip tata kelola perusahaan yang baik merupakan salah satu kunci sukses perusahaan untuk tumbuh dan menguntungkan dalam jangka panjang. ${ }^{10}$ Penerapan prinsip ini diyakini juga dapat menciptakan tata kelola yang baik bagi pengelolaan dan pengembangan perusahaan.

Prinsip tata kelola perusahaan yang baik secara umum mempunyai nilai-nilai positif dalam menjaga konsistensi serta profesionalisme perusahaan yang hendak melakukan berbagai macam perencanaan dan tindakan menuju kepada kinerja yang lebih baik. Hal ini didasarkan bahwa terdapat empat prinsip, yaitu pinsip kewajaran, keterbukaan informasi, dapat dipertanggungjawabkan dan pertanggungjawaban, yang jika dilasanakan dan diterapkan secara baik dan benar oleh suatu perusahaan maka dengan sendirinya akan

8 Sofyan Ahmad; Loc. Cit.

9 Izzati Nur Laili. (2011)."Pengaruh Penerapan Good Corporate Governance Terhadap Kinerja PT Kalbe Farma, Tbk". (Online), Repository, https://library.gunadarma.ac.id/repository/pengaruhpenerapangood-corporate-governanceterhadap-kinerja-keuanganpada-pt-kalbe-farma-tbk-ssm, diakses tanggal 13 Januari 2020.

10 Hidayat Ferli. (2008). "Pelaksanaan Good Corporate Governance Dalam UU Nomor 40 Tahun 2007 Tentang Perseroan Terbatas" Web Page, https://ferli1982.wordpress.com/2013/02/11/pelaksanaan-goodcorporate-governance-gcg-dalam-undang-undang-no-40-tahun-2007-tentang-perseroan-terbatas/, diakses tanggal 13 Januari 2020. 
membawa perusahaan tersebut kearah kemajuan dan sebaliknya apabila perusahaan tidak mau bekerja dengan menerapkan prinsip ini maka berbagai potensi negatif akan berkembang dan selanjutnya dapat mempengaruhi perkembangan dan pengelolaan perusahaan. Selain dapat membawa perusahaan menjadi baik, pelaksanaan prinsip tata kelola perusahaan yang baik dapat membantu pengurus untuk mempertanggungjawabkan pengelolaan perusahaan termasuk kewajiban-kewajibannya kepada pemangku kepentingan. ${ }^{11}$ Penerapan prinsip tata kelola perusahaan yang baik akan efektif jika dipatuhinya asas-asas yang terkandung didalamnya dalam kegiatan bisnis sehari-hari. Kepatuhan ini terlebih dahulu dimulai dan diterapkan oleh pengurus dan kemudian diikuti oleh segenap pengelola, karena sangat dibutuhkan penerapan yang konsisten, tegas dan berkesinambungan dari seluruh pelaku bisnis.

Berdasarkan uraian diatas, maka penelitian ini hadir sebagai salah satu wujud kepedulian terhadap pengelolaan Dana Desa pada Desa-Desa di Provinsi NTT karena walaupun sudah diatur sedemikian bagusnya namun dalam proses implementasi dilapangan (desa) sering mengalami hambatan. Khusus di Provinsi NTT dan lebih khususnya desa-desa di Kecamatan Kokbaun-Kabupaten TTS. Pembentukan dan pengembangan BUMDES berbasis prinsip Tata Keloa Perusahaan yang Baik, masih harus mendapat perhatian yang serius dari pemerintah desa, kecamatan dan pemerintah kabupaten. Berdasarkan data Dinas Pemberdayaan Masyarakat Desa dan Transmigrasi (DPMD) NTT, pada Tahun 2017 baru terbentuk 82 BUMDES yang tersebar di 21 kabupaten dengan 2.995 desa penerima alokasi dana desa. Data desa sampai Tahun 2019 ada 3.026 desa di NTT dengan jumlah 978 BUMDES, dari jumlah tersebut sebanyak 777 BUMDES berstatus aktif dengan total penyertaan modal Rp118 miliar yang berasal dari dana desa. ${ }^{12}$ Hal ini masih sangat jauh dari jumlah ideal pembentukan BUMDES. Khusus untuk Kabupaten TTS dari total 266 desa baru terbentuk 95 BUMDES, dan di Kecamatan Kokbaun dari jumlah 6 desa yang ada sesuai data Statistik Pemerintah Kabuapten TTS sudah terbentuk 5 (lima) BUMDES namun dalam pengelolaanya masih belum memenuhi harapan. Dalam penetapan Pepres Nomor 131 Tahun 2015 tentang Penetapan Desa teringgal Tahun 2015-2019, di Provini NTT terdapat 18 Kabupaten yang masuk dalam kategori tersebut dan satu dintaranya adalah Kabupaten TTS. Indikator penetapan desa tertinggal dilihat dari aspek : Perekonomian Masyarakat, Sumber Daya Manusia, Sarana dan Prasarana, Kemampuan Keuangan Daerah, Aksesibilitas dan Karateristik Daerah. ${ }^{13}$

Kecamatan Kokbaun adalah salah satu kecamatan di Kabupaten TTS yang dalam data BPS Kabupaten TTS menempati urutan ke-32 dari jumlah 32 kecamatan yang ada di Kabupten TTS. Selain menempati urutan terakhir, Kecamatan Kokbaun juga merupakan kecamatan paling luar karena berbatasan langsung dengan Kabuapten Malaka. Hal ini sejalan dengan program pemerintah RI adalah membangun dari tepi. Maka, sebagai pembanding dalam peneltian ini, peneliti memilih Kecamatan Kokbaun sebagai tempat peneltian.

Sebagai panduan metodologis dalam mencermati obyek penelitian, maka idntifikasi masalah yang memuat permasalahan penelitian, adalah : 1) Bagaimana respon Pemerintah Desa terhadap UU Desa yang mengamanatkan pembentukan BUMDES 2) Apa Hambatanhambatan Pembentukan dan pengembangan BUMDES 3) Bagaimana peranan prinsip tata

11 Ibid.

12 B. P. S. P. NTT. (2017). “Data Jumlah BUMDES di Kabupaten Timor Tengah Selatan”. [Online]. Available: https://ntt.bps.go.id/, diakses tanggal 13 Januari 2020.

13 VoN. (2017). "Sebanyak 18 Kabupaten di NTT Tergolong Daerah Tertinggal, Newspapaer Article”, https://voxntt.com/2017/06/12/sebanyak-18-kabupaten-di-ntt-tergolong-daerah-tertinggal/12911/ diakses tanggal 10 Januari 2020. 
kelola perusahaan yang baik dan penerapannya dalam pengeloaan BUMDES dalam Mendukung Pengembangan Ekonomi Masyarakat Desa.

\section{B. METODE PENELITIAN}

Penelitian ini adalah peneltian hukum deskritif (descriptive legal study) dengan tipe penelitian hukum normatif-empiris, yang dapat disebut juga penelitian hukum normatifterapan (applied law research). Pada tipe penelitian terdapat gabungan dua tahap kajian, yaitu, kajian mengenai hukum normatif yang belaku yang diperoleh dari inventarisasi bahan hukum dan kajian hukum empiris berupa penerapan (implementasi) pada peristiwa hukum in concreto guna mencapai tujuan yang telah ditentukan. Tipe penelitian hukum normatif-empiris membutuhkan data sekunder dan data primer. ${ }^{14}$ Metode pengumpulan data sekunder adalah studi dokumen (inventarisasi bahan hukum). Penelitian bahan hukum diperoleh dari peraturan perundang-undangan, buku-buku kepustakaan, browsing internet, dan dokumen-lainya. ${ }^{15}$ Metode pengumpulan data primer adalah melalui studi lapangan (field research) dengan cara wawancara kepada narasumber. ${ }^{16}$ Lokasi peneltian adalah 6 (enam) Desa di Kecamatan Kokbaun - Kabupaten TTS - Provinsi NTT. Populasi dalam penelitian ini adalah Aparat Desa di Kecamatan Kokbaun - Kabupten TTS. Mengingat luasnya daerah populasi maka peneliti mengambil sampel dalam penetuan responden. Peneliti menggunakan metode non probability sampling dengan tipe purposive sampling (penentuan reponden untuk tujuan tertentu). ${ }^{17}$ Dari 6 desa di Kecamatan Kokbaun, sampel yang diambil adalah 3 desa, yaitu Desa Lotas, Desa Niti dan Desa Obaki. Narasumber dan Respoden dalam penelitian ini adalah 3 Kepala Desa (Desa Lotas, Desa Niti dan Desa Obaki) di Kecamatan Kokbaun, Camat Kokbaun, Kepala BPMD Kab. TTS. Adapun aspek yang diteliti adalah: 1) Respon Pemerintah Desa terhadap kehadiran UU Desa yang mengamanatkan pembentukan BUMDES; 2) Hambatan pembentukan BUMDES; 3) Peranan Prinsip Tata Kelola Perusahaan Yang Baik dan Penerapanya dalam pengelolaan BUMDES Dalam Mendukung Pengembangan Ekonomi Masyarakat Desa. Data hasil penenelitian dianalisis secara deskritif kualitatif.

\section{PEMBAHASAN}

\section{Kondisi Objektif Kecamatan Kokbaun}

Kecamatan Kokbaun adalah sebuah Kecamatan yang terletak disebelah Selatan Kabupaten Timor Tengah Selatan, Provinsi Nusa Tenggara Timur. Kecamatan ini merupakan satu dari tiga puluh dua kecamatan yang ada di Kabupaten Timor Tengah Selatan. Letak geografis Kecamatan Kokbaun adalah sebalah Utara berbatasan dengan Kabupaten Belu, sebelah Selatan berbatasan dengan Kecamatan Toianas, sebelah Timur berbatasan dengan Kabupaten Malaka dan sebelah Barat berbatasan dengan Kecamatan Amnuban Utara.

14 Muhamad Kadir Abdul. (2004). Hukum dan Penelitian Hukum. Bandung: Citra Aditya Bakti, h. 24.

15 Amirudin A, Zainal H. (2004). Pengantar Metode Penelitian Hukum, Jakarta: Raja Grafindo Persada, h. 68 .

16 Mukti Fadjar, Achmad Y. (2013). Dualisme Penelitian Hukum Normatif dan Empiris, Yogyakarta: Pustaka Belajar, h.62.

17 Mamuji Sri. (2005). Metode Penelitian dan Penulisan Hukum, Jakarta: Fakultas Hukum Universitas Indonesia, h. 53. 


\section{Respon Pemerintah Desa terhadap kehadiran UU Desa yang mengamanatkan pembentukan BUMDES}

Adapun yang dimaksud dengan respon pemerintah desa terhadap Undang-Undang Desa yang mengamanatkan pengembangan dan pembentukan BUMDES dalam penelitian ini adalah pandangan atau tanggapan pemerintah desa terhadap beberapa butir pertanyaan, yaitu tentang sasaran, tujuan dan manfaat BUMDES, peraturan tentang pemmbentukan dan pelaksanaan BUMDES, tipe usaha BUMDES, kepemilikan BUMDES, dan sumber dana BUMDES.

Hasil penelitian menunjukkan bahwa respon Pemerintah Desa dan Kecamatan terhadap rencana pembentukan dan pengembangan BUMDES sebagaimana yang diamantkan oleh UU Desa adalah baik. Hal ini diketahui dari tanggapan dari responden yaitu Camat Kokbaun, Kepala Desa Lotas, Niti dan Obaki terhadap semua item pertanyaan. Artinya Pemerintah Desa dan Kecamatan Kokbaun yang menjadi sampel dalam penelitian ini memiliki pandangan yang baik dalam pembentukan, perencanaan dan pengembangan BUMDES. Pemerintah desa menyambut baik pembentukan dan pengembangan BUMDES sebagaimana yang telah diamanatkan Kementrian Desa. Hal ini terlihat dari masing-masing desa telah mempersiapkan berbagai hal yang dibutuhkan untuk membentuk dan mengembangkan BUMDES termasuk sudah mengalokasikan anggaran untuk pengembangan BUMDES ke dalam Alokasi Dana Desa sebagai langkah utama untuk merealisasikan rencana pengembangan BUMDES. Desa Niti dan Desa Obaki merupakan dua desa di Kecamatan Kokbaun yang sudah memiliki BUMDES dan sedangkan desa lotas masih dalam tahap perencanaan.

Adanya pandangan yang baik dari pemerintah desa dan kecamatan terhadap pengembangan BUMDES menunjukkan adanya pemahaman dari Camat dan Kepala Desa tentang arti penting BUMDES. Hasil wawancara dengan Camat Kokbaun dikatakan bahwa BUMDES sangat bermanfaat karena menjadi lemabaga ekonomi desa yang menjadi payung usaha untuk melindungi usaha kecil menengah di desa. BUMDES juga membantu mengatasi sistem ijon yang selama ini menghambat usaha masyarakat kecil serta BUMDES dapat meningkatkan pertumbuhan perekonomian masyarakat desa.

Berikut pemaparan tentang respon pemerintah desa terhadap pembentukan BUMDES sebagaimana yang diamantkan oleh UU Desa.

1) Respon terhadap Tujuan, Manfaat dan Sasaran pembentukan BUMDES

Respoon pemerintah desa Lotas, Niti dan Obaki terhadap tujuan, manfaat dan sasaran pembentukan BUMDES adalah mereka paham dan mengerti. Pemerintah Desa mengetahui bahwa tujuan, manfaat dan sasaran pembentukan BUMDES adalah masyarakat desa. BUMDES yang dibentuk dikelola oleh desa melalui kebijakan desa berupa penyediaan fasilitas umum atau pelayanana dasar yang dibutuhkan masyarakat desa. Hal ini ssejalan dengan tujuan dan manfaat pengembangan BUMDES yang ditetapkan melalui UU Desa yaitu untuk mendorong desa dalam memenuhi pelayanan dasar sesuai kebutuhan desa.

2) Respon terhadap Peraturan tentang Pembentukan danPelaksanaan BUMDES Pedoman dan aturan yang akan digunakan dalam pembentukan dan pengelolaan BUMDES adalah Peraturan Desa (Perdes) dan musyawarah desa yang dirumuskan langsung oleh perangkat desa dan pengurus melalui musyawarah desa diikuti peraturan Pemerintah Kecamatan. Desa Niti dan Obaki sudah mendirikan BUMDES yang diatur dalam Perdes sedangkan desa Lotas dalam perencanaan pembentukan BUMDES pada tahun 2020.

Pembentukan dan pengembangan BUMDES sebagaimana yang ditetapkan dalam 
Peraturan Kemendesa No. 4 Tahun 2015 tentang Pendirian, Pengurusan dan Pengelolaan serta Pembubaran BUMDES bahwa sistem pengelolaan BUMES dapat diterapkan sesuai dengan perdes. BUMDES adalah Badan usaha yang milik desa di bentuk oleh Pemerintahan Desa bersama Masyarakat Desa melalui MUSDES (Musyawarah Desa). Namun yang memiliki badan hukum adalah unit usaha pada BUMDES dapat menggunakan badan hukum PT maupun CV.

3) Respon terhadap Jenis Usaha BUMDES

Kepala desa Niti dan Obaki, Kecamatan Kokbaun pada pertanyaan tentang tipe usaha dalam rencana pengembangan BUMDES yang sudah terbentuk dimasig-masing desa mengatakan jenis usaha BUMDES bertitik berat pada usaha padat modal yang berbasis pada kebutuhan masyarakat desa serta potensi yang dimiliki desa yang dinilai sangat dibutuhkan masyarakat desa guna menunjang kelancaran aktivitas masyarakat. Usaha dan yang akan dijalankan di Niti dan Obaki dan Lotas (jika sudah mendirikan BUMDES) adalah bergerak pada bidang lembaga keuangan (simpan-pinjam). Kepala Desa Niti dan Obaki berpendapat akan memulai pengelolaan tipe usaha BUMDES secara bertahap yang diawali dengan bidang usaha pelayanan kemudian diikuti dengan usaha lainnya dimasa yang akan datang sesuai dengan kebutuhan masyarakat.

4) Respon terhadap Kepemilikan BUMDES

BUMDES adalah badan usaha desa yang mempunyai ciri utama yang berbeda dengan lembaga usaha lainnya yaitu kepemilikan secara bersama. BUMDES tidak hanya dimiliki oleh pemerintah desa melainkan menjadi milik pemerintah desa dan masyarakat. Hasil peneltian menunjukan bahwa Pemerintah Desa Niti, Obaki dan Lotas memiliki pandangan yang sama yaitu BUMDES adalah milik desa dan masyarakat desa dan dimanfaatkan secara bersama oleh kedua komponen ini. Pengelolaan BUMDES dilakukan oleh pengurus BUMDES dan diawasi oleh pemerintah desa. Saat ini semua sumber modal dalam pengembangan BUMDES masih berasal dari dana desa.

5) Respon terhadap Sumber Dana BUMDES

Menurut UU Desa dan Peraturan Pelaksanannya sumber dana BUMDES berasal dari dana desa dan investasi masyarakat desa. Ini berarti bahwa pemerintah desa dalam perencanaan pengembangan BUMDES selain mengalokasi dana desa tetapi juga dapat menerima penyertaan modal dari masyarakat desa sebagai bentuk investasi. Di desa Niti dan Obaki, alokasi dana melalui investasi dana dari masyarakat belum terwujud. Menurut Peraturan Pemerintah (PP) No. 43 Tahun 2014 pasal 135 menyatakan bahwa : "modal awal BUMDES bersumber dari APB Desa, dimana kekayaan BUMDES merupakan kekayaan desa yang dipisahkan dan tidak terbagi atas saham dan modal BUMES dapat berasal dari penyertaan modal desa serta penyertaan modal masyarakat desa". Lebih lanjut menurut Permendesa No. 19 Tahun 2017 tentang Prioritas Penggunaan Dana Desa bahwa berbagai kegiatan atau program dapat dilaksanakan dengan menggunakan dana desa, salah satu prioritas penggunaan dana desa adalah untuk pengembangan BUMDES.

\section{Hambatan-Hambatan pembentukan dan Pengembangan BUMDES}

Dari hasil penelitan di Desa Niti dan Obaki diperoleh data meski sudah berjalan satu tahun tetapi perkembangan BUMDES yang dibentuk dalam mendorong perkembangan kesejahteraan masyarakat melalui unit usaha yang dibangun masih jauh dari harapan. Menurut Kepala Badan Pemberdayaan Masyarakat Desa (BPMD) Kabupaten TTS, secara umum hambatan pembentukan BUMDES di Kabupaten TTS adalah aparat desa belum sepenuhnya memahami terkait fungsi dan manfaat dari keberadaan BUMDES, mereka mengetahui tengang BUMDES namun pada tataran implementasi terkadang mereka tidak 
paham. Selain itu tidak semua BUMDES yang telah dibentuk mampu mengeluarkan komoditi unggulannya untuk dijual keluar. Hal ini sejalan dengan hasil wawancara dengan Camat Kokbaun, yang mengatakan ada sejumlah kendala yang dijumpai dalam pembentukan BUMDES (untuk desa Lotas) dan pengembangan BUMDES yang sudah terbentuk, antara lain :

1) Sumber Daya Manusia Masyarakat Desa yang belum sepenuhnya memahami pentingnya pendirian dan pengembangan BUMDES sebagai salah satu organisasi yang dapat meningkatkan kesejateraan masyarakat.

2) Untuk pengembangan BUMDES yang sudah ada, hambatannya adalah pengurus BUMDES belum menajalankan Anggaran Dasar (AD) dan Anggaran Rumah Tangga (ART) BUMDES dengan baik serta kurangnya tenaga terampil untuk duduk sebagai pengurus BUMDES. Di samping itu hambatan lainnya adalah unit Usaha BUMDES yang sudah terbentuk tidak mencapai profit atau keuntungan yang ditentukan yang mengakibatkan operasional unit usaha menjadi macet.

3) Pemahaman perangkat desa terutama kepala desa mengenai pembentukan BUMDES bagi desa yang belum memiliki BUMDES masinh kurang. Hal ini dapat terjadi karena para kepala desa selama ini hanya memahami bahwa tugas mereka adalah sebagai pejabat administrative dan penanggung jawab proyek yang bekerja sesuai arahan dan petunjuk dari struktur pemerintah diatasnya, yaitu camat atau bupati. Perpanjangan tangan dari pemerintah. Akibatnya, aparat desa tidak mampu berpikir inovatif untuk mengembangkan potensi desa yang salah satunya adalah melalui BUMDES. BUMDES lebih menekankan kepada masalah yang berkaitan dengan bidang kewirausahaan. Lemahnya pemahaman mengenai BUMDES yang menekankan pada aspek kewirausahaan inilah yang membuat pembentukan dan pengembangan BUMDES tidak tersosialisasi dengan sempurna kepada warga desa (masyarakat).

4) Konsep pembangunan desa hanya dipahami secara terbatas pada pembangunan fisik. Hal ini dikarenakan pembangunan fisik lebih jelas terlihat dan mudah untuk dinilai dan dikatakan berprestasi jika telah dilaksanakansesuai dengan arahan. Pembangunan ini tidak membutuhkan kreatifitas karena hanya didasarkan atas petunujuk dan pengawasan dari struktur pemerintah diatasnya, ini berbeda jika dibandingakan dengan pembentukan BUMDES yang membutuhkan kreatifitas.

Untuk mengatasi hambata-hambatan diatas, maka pemerintah Kecamatan Kokbaun mengupayakan komunikasi dan sosialisasi tentang perlunya dibentuk dan dikembangkan BUMDES kepada Kepala Desa dan Perangkat Desa bersama Tokoh masyarakat dan tokoh Adat. Untuk mewujudkan tujuan tersebut, maka pemerintah desa menetapkan peraturan tentang pembentukan BUMDES melalui musyawarah bersama masyarakat desa. Aturan yang dibuat dan ditetapkan memuat maksud serta tujuan pembentukan BUMDES, lingkup kegiatan BUMDES, pengurus, pengelolaan keuangan serta mekanisme pertanggungjawaban pelaksanaan BUMDES. Langkah selajutnya adalah pemerintah mengalokasikan belanja APBDesa untuk pendirian BUMDES yang bersumber dari dana desa dalam bentuk belanja modal, barang/jasa, atupun menjadi modal usaha.

Hal ini sesuai dengan yang diamantakan dalam pasal 135, PP Nomor 43 Tahun 2014 tentang Peraturan Pelaksanaan UU Desa yang menyebutkan bahwa modal utama pendirian BUMDES adalah berasal dari APBDesa. Perseroan Terbatas (PT) dan/atau Lembaga Keuangan Mikro (LKM) adalah unit usaha yang dapat didirikan dengan modal yang ada pada BUMDES. Namun dalam pelasanaanya BUMDES yang belum berniat mendirikan unit usaha, maka BUMDES tersebut dapat dijalankan berdasarkan Peraturan Desa yang terlah ditetapkan dan pemerintah desa memisahkan kekayaan desa utuk dikelola oleh BUMDES 
sehingga dapat meningkatkan usaha BUMDES. ${ }^{18}$

\section{Pengelolaan BUMDES Berbasis Prinsip Tata Kelola Perusahaan Yang Baik}

Menurut Pusat Kajian Dinamika Sistem Pembangunan Tahun, pengelolaan BUMDES harus dillaksanakan dengan memperhatikan dan menggunakan prinsip-prinsip tata kelola BUMDES yang baik, yaitu: prinsip kooperatif, partisipatif, emansipatif, transparansi, akuntable, dan sustainable. Pelaksanaan prinsip ini harus didukung dengan adanya mekanisme saling menguatkan dan saling membantu antara apparat desa, masyarakat dan pengelola BUMDES dan diharapkan dilakukan secara profesional, transparent dan otonom. ${ }^{19}$ Oleh karena itu informasi yang jelas dan tepat tentang kekhasan desa termasuk didalamnya adalah ciri kehidupan sosial dan budaya masarakatnya menjadi penting dalam usaha membentuk dan mengembangkan BUMDES terutama dalam memproyeksikan peluang pasar dari produk (barang dan jasa) yang dihasilkan. ${ }^{20}$

Sebagai badan usaha yang mandiri, BUMDES di dirikan melalui inisiatif masyarakat desa. Inisiatif ini erat kaitanya dengan sumber pendanaan atau modal BUMDES yang selain berasal dari pemerintah desa juga diperoleh lewat partisipasi masyarakat dan dimungkinkan juga diperoleh dari pemerintah kecamatan atau kabupaten atau melalui ketiga lainnya dalam bentuk pinjaman. Mekanisme untuk mendapatkan sumber modal BUMDES harus didasarkan kepada peraturan perundang-undangan. Pengaturan-pengaturan lebih lanjut mengenai BUMDES diatur secara lengkap dan jelas dalam Peraturan Desa. ${ }^{21}$

BUMDES didirikan untuk maksud dan tujuan yang jelas. Tujuan berdirinya BUMDES adalah memberikan pelayanan kebutuhan untuk usaha produktif terutama bagi kelompok miskin di yang ada di desa-desa, mengurangi praktek hutang dengan bunga yang tinggi, menciptakan kesempatan berusaha dan pada akhirnya pendapatan masyakarat desa mampu ditingkatkan. Kehadiran BUMDES diharapkan dapat juga memberikan edukasi/pendidikan kepada masyarakat untuk terbiasa menabung sehingga pada akhirnya kehadiran BUMDES dapat mewujudkan masyarakat yang mandiri serta mampu mendorong pembangunan dan pengembangan ekonomi masyarakat desa. Hal ini erat kaitanya dengan maksud dan tujuan pendirian BUMDES yaitu untuk meningkatkan Pedapatan Asli Desa sehingga pada akhirnya BUMDES dapat mendukung dan menunjang program-program pembangunan desa dan salah satu tujuan BUMDES adalah memberikan pelayanan kepada masyarakat. ${ }^{22}$

Pengelolaan dan pengembangan BUMDES dilaksanakan dengan merujuk kepada prinsip-prinsip pengelolaan BUMDES yang baik. Hal ini menjadi penting untuk diuraikan karena dapat memberikan pemahaman kepada pemerintah desa, anggota (penyerta modal), Pemerintah kecamatan dan kabupaten serta masyarakat sebagai para pelaku BUMDES, dalam teori pengelolaan BUMDES dilakukan dengan memperhatikan 6 (enam) prinsip

18 Dewi A. S. K., \& Prasetyo N. D. (2015). Interpretasi Bentuk Badan Usaha Milik Desa Menurut Undang-Undang Nomor 6 Tahun 2014 tentang Desa, Jurnal Media Hukum, doi: 10.18196/jmh.2015.0059. Volume 22, Nomor 2. h. 243.

19 Ridlwan Z. (2015). Urgensi Badan Usaha Milik Desa (Bumdes) Dalam Pembangun Perekonomian Desa, Jurnal Ilmu Hukum Fiat Justisia, doi: 10.25041/fiatjustisia, Volume 8, Nomor 3. h. 314.

20 Satoto S., Syarif A., Noviades D., Fitria F., \& Mushawirya R. (2019). Sosialisasi Terhadap Pembentukan Badan Usaha Milik Desa Menurut Undang-Undang Nomor 6 Tahun 2014 Tentang Desa, Jurnal Karya Abdi Masyarakat, doi: 10.22437/jkam, Volume 3, Nomor 2. Tanpa h.

${ }^{21}$ Dewi A. S. K., Prasetyo N. D. Loc.Cit.

22 Soetpo Yudhianto Imam. (2010). "Mengejawantahkan Peran dan Eksistensi Bumdes", Web Page, [Online]: https://pdpmmagetan.wordpress.com/2010/11/19/mengejawantahkan-peran-eksistensi-bumdes/, diakses tanggal 12 Januari 2020. 
dalam mengelola BUMDES ${ }^{23}$, yaitu:

1) Kooperatif

Kooperatif adalah semua pelaku BUMDES dan yang terlibat dalam pengurusan BUMDES harus dapat bekerjasama dengan baik untuk mengembangkan dan mejaga kelangsungan usaha BUMDES. Kerja sama yang sinergis antara pengurus, masyarakat, pemerintah desa dan instansi terkait lainya dibutuhkan karena BUMDES adalah salah satu modal dalam pengembangan ekonomi masyarakat ditingkat desa yang berfungsi sebagai lembaga sosial dan lembaga komersil, sebagai lembaga sosial, maksud pendirian BUMDES adalah menyediakan pelayanan kebutuhan yang penting bagi masyarakat. Sedangkan sebagai lembaga komersial tujuan pendirian BUMDES adalah melalui penawaran sumberdaya lokal (barang dan jasa) ke pasar dengan tujuan untuk memperoleh keuntungan. BUMDES sebagai badan hokum didirikan dan bentuk melalui hasil kesepakatan masyarakat dan pemerintah desa dan disahkan melalui peraturan perundang-undangan sehingga dalam menjalankan usahanya prinsip kooperatif harus selalu diperhatikan.

2) Partisipatif

Partisipatif adalah semua seluruh pelaku usaha yang terlibat dalam pendirian dan pengembangan BUMDES harus memberikan dukungan dan kontribusi yang dapat mendorong kemajuan usaha BUMDES. Peran pemerintah adalah melalukan sosialisasi kepada masyarakat tentang pentingnya BUMDES dan peran masyarakat adalah partisipasinya dalam memantau pengelolaan dan pengembangan BUMDES. Partisipasi yang terutama dari masyarakat desa adalah pemenuhan modal usaha BUMDES. Hal ini didasarkan sebagai suatu lembaga ekonomi, modal usaha BUMDES di bangun atas inisiatif masyarakat. Walaupun demikian modal BUMDES juga dapat berasal dari pihak lain dalam hal ini pinjaman dari pihak ketiga. Hal ini sesuai dengan yang diamanatkan oleh UU Pemerintahan Daerah.

3) Emansipatif

Emansipatif disini dirtikan sebagai tidak adanya perbedaan dalam pengelolaan dan pengurusan BUMDES. Pengurusan dan pengelolaan BUMDES tidak dikaitkan dengan perbedaan apapun dan diserahkan sepenuhnya kepada masyarakat, dalam melaksanakan prinsip ini masyarakat harus dipersiapkan untuk dapat menerima gagasan yang diemban oleh BUMDES sebagai lenbaga yang memiliki dua fungsi yaitu fungsi sosial dan fungsi komersial. Sosialisasi, pelatihan dan Pendidikan adalah metode yang digunakan untuk menyebarluaskan tentang maksud dan tujuan didirikan dan dikembangkan BUMDES.

4) Transparan

Pengelolaan BUMDES, keterbukaan terhadap tata kelola BUMDES memegang peranan yang sangat penting. Hal ini didasarkan kepada pendirian BUMDES bersentuhan langsung dengan kepentingan masyarakat. Mengingat BUMDES didirikan di Desa maka nilai yang diperjuangkan adalah nilai kejujuran dan keterbukaan. Dalam menjalankan usahanya BUMDES harus mampu memberikan kontribusi yang nyata terhadap peningkatan kesejahteraan masyarakat desa dan mampu mengembangkan kehidupan ekonomi masyarakat desa.

5) Akuntabel

Akuntabel adalah semua aktivitas usaha BUMDES harus dapat dipertanggung jawabkan baik secara administratif maupun secara teknis. BUMDES didirikian dengan maksud berbagai pengelolaan ekonomi produktif desa yang dilakukan harus berjalan

23 Amanda H. W. (2015). Strategi pembangunan desa dalam meningkatkan oendapatan asli desa melalui Badan Usaha Milik Desa (Bumdes), Jurnal Publika, Volume 3, Nomor 5. Tanpa h. 
secara efektif dan efisien, professional, mandiri dan semuanya dapat dipertanggungjawabkan kepada pemangku kepentingan yaitu pemerintah desa dan masyarakat. Pengelolaan BUMDES harus diljalankan sesuai standar dan mampu menerikan pelayanan kepada masyarakat desa karena BUMDES menjadi usaha desa yang paling dominan dalam menggerakan ekonomi masyarakat. Harus ada mekanisme tata kelola kelembagaab yang sesuai dengan aturan yang disepakati bersama dalam musyawarah desa.

6) Sustainabel

Sustainable adalah mendorng pembangunan ekonomi masyarakat desa secara mandiri dan berkelanjutan. Kegiatan usaha ynng dikembangkan oleh BUMDES harus dapat mewujudkan pemberdayaan ekonomi masyarakat desa. Melalui BUMDES, Alkosi Dana Desa yang disediakan akan membantu dan memberdayakan proses penguatan aspek ekonomi mayarakat desa. Pengeloaan BUMDES ditopang juga dengan adanya anggaran dari Alokasi Dana Desa. Jika pengeloaan BUMDES dilakukan dengan baik dan transparan serta akuntable maka akan berkolerasi postif terhadap peningkatan pendapatan asli desa yang pada akhirnya dapat digunakan unutk pembagunan desa.

Sesuai dengan penjelasan 6 prinsip diatas maka dalam proses dan upaya pembangunan dan penguatan ekonomi masyarakat desa yang diwujudakan dalam pembentukan BUMDES adalah penguatan kerja sama sehingga tujuan untuk mengatasi kemiskinan dan pengangguran dapat ditekan dan sekaligus dapat membuka akses pasar yang dapat menjadi daya dorong dalam peningkatan kesejahteraan masyarakat desa.

Penjelasan mengenai prinsip pengelolaan BUMDES tidak terlepas dari pembahasan mengenai Prinsip Tata Kelola Perusahaan Yang Baik. Keterkaitan antara kedua prinsip ini sebagaiman yang dimaksud dalam penelitian ini adalah mengacu pada Pedoman Umum Tata Kelola Perusahaan Yang Baik, Indonesia Tahun 2006 sebagai berikut ${ }^{24}$ :

1) Transparansi (Transparency)

BUMDES yang didirikan dan dikembangkan harus dapat menjaga obyektivitasnya dalam menjalankan bisnis. Penyediaan informasi yang relevan bagi pemangku kepantingan harus dapat diakses dengan mudah dan cepat serta dapat dipahami.

2) Akuntabilitas (accountability)

Pertaggungjawaban kinerja harus dilalkukan oleh BUMDES. Sebagai sebuah perusahaan pertanggungjawaban kinerja harus dilakukan secara transparan dan wajar. Pengelolaan dan pengembangan BUMDES harus dilaksanakn secara benar sesuai dengan tjuan pendirian BUMDES dengan memperhatikan kepentingan masyarakat desa. Prinsip akuntabilitas ini memungkinkan untuk dicapainya kinerja yang berkesinambungan karena ini merupakan prasyarat jika BUMDES tetap dipertahankan sebagai salah satu pilar pembangunan ekonomi masyarakat desa.

3) Responsibilitas (Responsibility)

Organ atau pengurus BUMDES Bersama pemerintah desa harus mengetahui perubahan peraturan perundangundangan yang mengatur tentang BUMDES dan mampu mematuhi peraturan perundang-undangan tersebut serta dapat melaksanakannya dengan penuh tanggung jawab sehingga dapat dipertanggungjawabkan kepada masyarakat desa, pemerintah desadan pihak ketiga yang berkepentingan terhadap BUMDES.

4) Independensi (Independency)

24 Adhari A., Ismaidar I. (2017). Analisis Hukum Pembentukan Badan Usaha Milik Desa Dalam Upaya Meningkatan Pendapatan Asli Desa Di Kecamatan Babalan Kabupaten Langkat, Jurnal Hukum Bisnis dan Investasi, doi: 10.28932/di.v9i1, Volume 9, Nomor 1. Tanpa h. 
Pengelolaan BUMDES harus dilakukan secara mandiri dan bebas dari berbagai kepentingan. Kepenetingan ini baik yang dating dari luar maupun dari dalam BUMDES sendiri. Tidak ada saling mendomnasi dan intervensi diantara sesame pengurus BUMDES.

5) Kewajaran dan Kesetaraan (Fairness)

Dalam pengelolaan BUMDES kepentingan masyarakat desa, pemerintah desa dan pihak ketiga lainya harus senantiasa dijaga oleh pengurus BUMDES dengan memperhatikan aspek kewajaran dan kesetaraan.

Berdasarkan pemaparan diatas maka dapat dikatakan bahwa walaupun dalam pengelolaannya terdapat banyak aturan dan payung hukum namun disisi lain pendirin BUMDES sangat penting dalam mendukung pembangunan dan kesejahteraan desa. Hal ini disebabkan BUMDES dapat mendorong penerimaan kas yang dapat digunakan sebagai salah satu sumber pendapatan desa yang pada akhirnya akan berdampak terhadap pembangunan desa. Selain itu, dengan hadirnya BUMDES dapat mewujudkan desa yang mandiri dan otonom juga dapat meningkatkan daya saing desa yang akan berpengaruh kepada kemajuan desa itu sendiri. ${ }^{25}$ Dengan hadirnya BUMDES maka dengan sendirinya akan meningkatkan sesejahteraan masyarakat desa. Hal dikarenakan pengelolaan BUMDES berada ditangan masyarakat desa dan pemerintah desa dan pengelolaan tersebut dilakukan secara terbuka dan dapat dipertanggungjawabkan sesuai dengan prinsip tata kelola pengembangan BUMDES dan bermuara kepada Prinsip Tata Kelola Perusahaan Yang baik. Dalam pengembangan usaha BUMDES masyarakat desa dituntut dan diharapkan untuk berperan aktif dan kreatif dalam upaya memajuakan BUMDES. ${ }^{26}$

\section{P E N U T U P}

Berdasarkan pembahasan di atas, maka dapat disimpulkan bahwa pemerintah Desa dan Kecamatan Kokbaun, Kabupaten TTS merespon dengan baik tentang maksud dan tujuan pembentukan BUMDES. Hal ini dibuktikan dengan telah dibentuknya BUMDES pada 5 (lima) desa dan 1 (satu) desa masih dalam perencanaan. Walaupun dalam tataran pelaksanaannya ada ditemukan hambatan namun secara umum dipahami bahwa pembentukan BUMDES bertujuan sebagai penggerak pembangunan ekonomi masyarakat tingkat desa dengan tujuan akhir adalah meningkatkan taraf ekonomi masyarakat desa. Hambatan-hambatan dalam pembentukan dan pengembangan BUMDES lebih didasarkan kwalitas Sumber Daya Manusia yaitu pada kurangnya pemahaman aparat desa dan warga desa dan kurangnya tenaga yang terampil dalam pengelolaan BUMDES sesuai AD/ART serta pemahaman tentang pembangunan desa. Penerapan prinsip-prinsip Tata Kelola Perusahaan Yang Baik dalam pengelolaan BUMDES dapat menciptakan kelancaran pengelolaan bisnis perusahaan, termasuk meningkatkan daya saing. Nilai-nilai posotf yang terdapat dalam Prinsip Tata Kelola Perusahaan Yang Baik dapat menjaga konsistensi serta profesionalisme perusahaan dalam melakukan berbagai macam tindakan menuju kearah kinerja yang lebih baik. Prinsip Tata Keloa Perusahaan Yang Baik memiliki prinsip yang jika diterapkan secara baik dan benar akan membawa perusahaan dalam hal ini BUMDES kearah kemajuan. Pemberdayaan pemerintah dan masyarakat desa, dimaknai secara baru sebagai upaya menegakkan tata kelola desa yang demokratis. Demokratis dalam pengertian bahwa dalam pengelolaan BUMDES harus ada kerjasama antara masyarakat dengan pemerintah

25 Aziz Letty Latifah Nyimas. (2016). Otonomi Desa Dan Efektivitas Dana Desa, Jurnal Penelitian Politik, doi: 10.20885/unisia, Volume 13, Nomor 2. Tanpa h.

26 Soetpo Yudhianto Imam. Loc.Cit 
desa dalam hal ini adalah Aparatur Desa, dengan adanya pemberdayaan ini maka pengelolaan BUMDES dapat dijalankan dengan baik dan mencapai sasaran untuk peningkatan kesejahteraan masyarakat desa.

\section{DAFTAR PUSTAKA}

\section{Jurnal}

[1] Dewi, A. S. K., \& Prasetyo, N. D. (2015). Interpretasi Bentuk Badan Usaha Milik Desa Menurut Undang-Undang Nomor 6 Tahun 2014 tentang Desa. Jurnal Media Hukum, doi: 10.18196/jmh.2015.0059.242-257

[2] Adhari, A., \& Ismaidar, I. (2017). Analisis Hukum Pembentukan Badan Usaha Milik Desa Dalam Upaya Meningkatan Pendapatan Asli Desa Di Kecamatan Babalan Kabupaten Langkat. Jurnal Hukum Bisnis dan Investasi, doi: 10.28932/di.v9i1.728.

[3] Amanda, H. W. (2015). Strategi pembangunan desa dalam meningkatkan oendapatan asli desa melalui Badan Usaha Milik Desa (Bumdes): Studi pada badan pengelola air minum (Bpam) Di Desa Ketapanrame Kecamatan Trawas Kabupaten Mojokerto. Publika, Issn: 2354-600x

[4] Aziz, N. L. L. (2016). Otonomi Desa Dan Efektivitas Dana Desa. Jurnal Penelitian Politik, doi: 10.20885/unisia.vol27.iss53.art12

[5] Ridlwan, Z. (2015). Urgensi Badan Usaha Milik Desa (Bumdes) Dalam Pembangun Perekonomian Desa. Fiat Justisia, doi: 10.25041/fiatjustisia.v8no3.31

[6] Satoto, S., Syarif, A., Noviades, D., Fitria, F., \& Mushawirya, R. (2019). Sosialisasi Terhadap Pembentukan Badan Usaha Milik Desa Menurut Undang-Undang Nomor 6 Tahun 2014 Tentang Desa. Jurnal Karya Abdi Masyarakat, doi: 10.22437/jkam

[7] Shohibuddin, M. (2016). Peluang dan Tantangan Undang-undang Desa dalam Upaya Demokratisasi Tata Kelola Sumber Daya Alam Desa: Perspektif Agraria Kritis. Masyarakat Jurnal Sosial, doi: 10.7454/mjs.v21i1.5021

\section{Buku}

[8] Amirudin \& Azikin Z. H. (2004). Pengantar Metode Penelitian Hukum. Jakarta: Raja Grafindo Persada.

[9] Fadjar Mukti A.Y. (2013). Dualisme Penelitian Hukum Normatif dan Empiris. Yogyakarta: Pustaka Belajar.

[10] Mamuji S. (2005). Metode Penelitian dan Penulisan Hukum.Jakarta: Fakultas Hukum Universitas Indonesia.

[11] Muhamad Kadir Abdul (2004). Hukum dan Penelitian Hukum. Bandung: Citra Aditya Bakti.

[12] Tanya L. Bernad, Simanjuntak N. Yoan (2006). Teori Hukum, Strategi Tertib Manusia Lintas Ruang dan Generasi. Surabaya: Kita

\section{Online/World Wide Web}

[13] B. P. S. P. NTT (2017). "Data Jumlah BUMDES di Kabupaten Timor Tengah Selatan". [Online]. Available: https://ntt.bps.go.id/.

[14] Forum Pengembangan Pembaharuan Desa (2013). "Sharing Pembelajaran Bumdes Bagi Pemerintah Kabupaten/Kota", Web Page, [Online]. Available: http://www.forumdesa.org/?pilih=news\&mod=yes\&aksi=lihat\&id=1.

[15] Hidayat Ferli (2008). "Pelaksanaan Good Corporate Governance Dalam UU Nomor 40 
Tahun 2007 Tentang Perseroan Terbatas", Web Page, [Online]. Available: https://ferli1982.wordpress.com/2013/02/11/pelaksanaan-good-corporate-governancegcg-dalam-undang-undang-no-40-tahun-2007-tentang-perseroan-terbatas/.

[16] Izzati Nur Laili "Pengaruh Penerapan Good Corporate Governance Terhadap Kinerja PT Kalbe Farma, Tbk.," Repositiry Univiversitas Gunadarma, https://library.gunadarma.ac.id/repository/pengaruh-penerapangood-corporategovernanceterhadap-kinerja-keuanganpada-pt-kalbe-farma-tbk-ssm.

[17] Sani Abdul (2017). "Media Informasi Otonomi Daerah Indonesia, Tujuan Otonomi Daerah", Web Page, [Online]. Available: http://otonomidaerah.com/tujuan-otonomidaerah.

[18] Sofyan Ahmad (2015). "Pendirian dan Pengelolaan BUMD", Web Page, [Online]. Available: http://www.keuangandesa.com/2015/09/pendirian-dan-pengelolaan-badanusaha-milik-desa/.

[19] Soetpo Yudhianto Imam (2010). "Mengejawantahkan Peran dan Eksistensi Bumdes", Web Page, [Online]. Available: https://pdpmmagetan.wordpress.com/2010/11/19/mengejawantahkan-peran-eksistensibumdes/.

[20] Surya Putra Anom (2015). "Badan Usaha Milik Desa: Spirit Usaha Kolektif Desa, Jakarta: Jakarta: Kementerian Desa, Pembangunan Daerah Tertinggal, Dan Transmigrasi Republik Indonesia", https://www.academia.edu/11850491/_Free_Download_BUM_Desa_Spirit_Usaha_K olektif Desa.

[21] VoN (2017). "Sebanyak 18 Kabupaten di NTT Tergolong Daerah Tertinggal", Newspapaer Article, Kupang: VOX NTT.

[22] Wikipedia (2020). Otonomi Daerah Di Indonesia, Web Page, [Online]. Available: http://id.wikipedia.org/wiki/Otonomi_daerah_di_Indonesi. 